\title{
CD1 expression and CD1-restricted $T$ cell activity in normal and tumour-bearing human liver
}

\author{
Tony Kenna • Margaret O'Brien • Andrew E. Hogan • \\ Mark A. Exley • Steven A. Porcelli • John E. Hegarty • \\ Cliona O'Farrelly • Derek G. Doherty
}

Received: 26 May 2006 / Accepted: 25 July 2006 / Published online: 22 August 2006

(C) Springer-Verlag 2006

\begin{abstract}
CD1d-restricted natural killer T (NKT) cells expressing invariant $\mathrm{V} \alpha 14 \mathrm{~J} \alpha 18 \mathrm{~T}$ cell receptor $\alpha$ chains are abundant in murine liver and are implicated in the control of malignancy, infection and autoimmunity. Invariant NKT cells have potent anti-metastatic
\end{abstract}

T. Kenna $\cdot$ M. O'Brien · C. O'Farrelly

Education and Research Centre, St. Vincent's University

Hospital, Elm Park, Dublin 4, Ireland

\author{
A. E. Hogan · D. G. Doherty $(\bowtie)$ \\ Institute of Immunology and Department of Biology, \\ National University of Ireland, Maynooth, Maynooth, \\ Co. Kildare, Ireland \\ e-mail: derek.g.doherty@nuim.ie
}

M. A. Exley

Cancer Biology Program, Hematology and Oncology

Division, Beth Israel Deaconess Medical Center and Harvard

Medical School, Boston, MA, USA

S. A. Porcelli

Department of Microbiology and Immunology,

Albert Einstein College of Medicine, New York, NY, USA

J. E. Hegarty

Liver Unit, St. Vincent's University Hospital, Elm Park,

Dublin 4, Ireland

J. E. Hegarty $\cdot$ C. O'Farrelly

Conway Institute of Biomolecular and Biomedical Research,

University College Dublin, Dublin 4, Ireland

Present Address:

T. Kenna

Centre for Immunology \& Cancer Research,

The University of Queensland, Princess Alexandra Hospital,

Woolloongabba, Australia effects in mice and phase I clinical trials involving their homologues in humans are ongoing. However, invariant NKT cells are less abundant in human liver $(\sim 0.5 \%$ of hepatic T cells) than in murine liver (up to $50 \%$ ) and it is not known if other hepatic $\mathrm{T}$ cells are CD1restricted. We have examined expression of $\mathrm{CD} 1 \mathrm{a}$, CD1b, CD1c and CD1d mRNA and protein in human liver and evaluated the reactivity of mononuclear cells (MNC) from histologically normal and tumour-bearing human liver specimens against these CD1 isoforms. Messenger RNA for all CD1 isotypes was detectable in all liver samples. CD1c and CD1d were expressed at the protein level by hepatic MNC. CD1d, only, was detectable at the cell surface, but CD1c and CD1d were found at an intracellular location in significant numbers of liver MNC. CD1b was not expressed by MNC from healthy livers but was detectable within MNC in all tumour samples tested. Hepatic $\mathrm{T}$ cells exhibited reactivity against $\mathrm{C} 1 \mathrm{R}$ cells expressing transfected CD1c and CD1d, but neither CD1a nor CD1b. These cells secreted interferon- $\gamma($ IFN- $\gamma)$ but not interleukin-4 (IL-4) upon stimulation. In contrast, similar numbers of peripheral $\mathrm{T}$ cells released 13- and 16-fold less IFN- $\gamma$ in response to $\mathrm{CD} 1 \mathrm{c}$ and $\mathrm{CD} 1 \mathrm{~d}$, respectively. CD1c and CD1d expression and $\mathrm{T}$ cell reactivity were not altered in tumour-bearing liver specimens compared to histologically normal livers. These data suggest that, in addition to invariant CD1d-restricted NKT cells, autoreactive $\mathrm{T}$ cells that recognise CD1c and $\mathrm{CD} 1 \mathrm{~d}$ and release inflammatory cytokines are abundant in human liver.

Keywords Human $\cdot$ Liver $\cdot \mathrm{T}$ cells $\cdot$ Natural killer T cells $\cdot$ Tumour immunity 


$\begin{array}{ll}\text { Abbreviations } \\ \alpha \text { GC } & \alpha \text {-Galactosylceramide } \\ \text { ELISA } & \text { Enzyme-linked immunosorbent assay } \\ \text { GAPDH } & \text { Glyceraldehyde phosphate dehydrogenase } \\ \text { IL } & \text { Interleukin } \\ \text { IFN- } \gamma & \text { Interferon- } \gamma \\ \text { MAb } & \text { Monoclonal antibody } \\ \text { MHC } & \text { Major histocompatibility complex } \\ \text { MNC } & \text { Mononuclear cells } \\ \text { NK } & \text { Natural killer } \\ \text { NKT } & \text { Natural killer T } \\ \text { PCR } & \text { Polymerase chain reaction } \\ \text { TCR } & \text { T cell receptor }\end{array}$

\section{Introduction}

CD1 molecules comprise a family of glycoproteins that share structural similarities with major histocompatibility complex (MHC) molecules and are specialised in the presentation of lipid antigens to $\mathrm{T}$ cells [7, 46]. CD1-restricted $\mathrm{T}$ cells play key roles in anti-tumour defence in mice. Specific activation of these cells in vivo results in rapid anti-tumour cytotoxicity and IFN$\gamma$ production, which can prevent tumour metastasis and promote tumour rejection [14, 28, 41, 50]. CD1restricted $\mathrm{T}$ cells are therefore potential targets for immunotherapy for cancer and phase I trials using CD1-binding glycolipids are ongoing [25, 42].

Most therapeutic studies involving CD1-restricted $\mathrm{T}$ cells have been confined to the use of a population of CD1d-restricted $\mathrm{T}$ cells which expresses natural killer (NK) cell receptors and a T cell receptor (TCR) consisting of an invariant $\alpha$-chain $(\mathrm{V} \alpha 14 \mathrm{~J} \alpha 18$ in mice and $\mathrm{V} \alpha 24 \mathrm{~J} \alpha 18$ in humans), which pairs with one of a limited number of $\beta$-chains $[25,42]$. In both species, these "invariant" NKT cells display rapid and potent cytolytic activity and secretion of cytokines (IFN- $\gamma$, IL-2, IL-4 and IL-10), which direct adaptive immune responses [4, 7, 11, 19, 51]. In mice, invariant $\mathrm{V} \alpha 14 \mathrm{~J} \alpha 18^{+}$NKT cells generally account for $\sim 5 \%$ of peripheral blood $\mathrm{T}$ cells but they are highly enriched in liver, accounting for $30-50 \%$ of all $\mathrm{T}$ cells at this location $[4,18]$. In contrast, human invariant NKT cells expressing the homologous V $\alpha 24 \mathrm{~J} \alpha 18 \mathrm{TCR} \alpha$-chain are found in significantly lower numbers in human blood $(\sim 0.02 \%$ of $\mathrm{T}$ cells $)$ and liver $(\sim 0.5 \%)[30,33,38]$ and immunotherapy involving invariant NKT cells is less efficacious than in mice [25, 42]. However, T cells expressing the NK-associated receptors, CD56, CD161, CD94 and killer Ig-like receptors are substantially enriched in adult human liver [16, 43]. Like NKT cells, they display potent cytolytic activity and prompt cyto- kine secretion but they do not carry invariant TCR chains. It is not known if these NK-like T cells include functional equivalents of murine NKT cells. If they do they could be important potential targets for cancer immunotherapy, based on studies on murine disease models $[14,28,41,50]$.

While mice encode a single CD1 isoform, CD1d, humans have five isoforms, CD1a-e, of which CD1a, CD1b, CD1c and CD1d have been shown to stimulate T cells. CD1a, b and c are expressed by dendritic cells and other antigen-presenting cells and can present a range of lipids (mycolic acids, mycolates esterified to simple sugars, phosphatidyl inositol moieties linked to complex glycans, polyisoprenoid lipids and lipopeptides) derived from the cell walls of mycobacteria to $T$ cells $[7,46]$. CD1d is expressed by various myeloid, epithelial, parenchymal, and vascular smooth muscle cells in non-lymphoid organs [7, 10, 39, 46] and can present the $\alpha$-anomeric glycolipid, $\alpha$-galactosylceramide $(\alpha \mathrm{GC})$, found in marine sponges [31] and glycosphingolipids from Gram-negative bacteria that do not contain lipopolysaccharide [34] to subsets of T cells. Many CD1-restricted T cells can also be stimulated by exposure to antigen-presenting cells expressing CD1a, CD1b, CD1c or CD1d in the absence of added antigen [19, 45]. This autoreactivity probably results from $\mathrm{T}$ cell recognition of endogenous lipid antigens, such as phospholipids, gangliosides, sulphatides and the lysosomal glycosphingolipid, isoglobotrihexosylceramide, which have been shown to bind to human and murine $\mathrm{CD} 1$ and activate CD1restricted $\mathrm{T}$ cells $[27,48,49,60]$.

To ascertain whether the human liver contains functional equivalents of murine invariant CD1d-restricted $\mathrm{T}$ cells, we have examined the expression of CD1a, CD1b, CD1c and CD1d mRNA and protein in liver samples taken from healthy donors and patients with hepatic malignancy. Since there are no defining phenotypic markers for $\mathrm{T}$ cells restricted by CD1a, CD1b and CD1c [7, 26, 46, 53] and non-invariant CD1d-restricted T cells which express diverse $\alpha \beta$ or $\gamma \delta$ TCRs with multiple rearranged junctional sequences have been described [3, 12, 21, 44], we have evaluated the reactivity of hepatic $\mathrm{T}$ cells against a panel of transfectant cells expressing CD1a, CD1b, CD1c and CD1d. Our data indicate that, although invariant NKT cells constitute only a small proportion of human hepatic T cells, $\mathrm{CD} 1 \mathrm{c}$ and CD1d are expressed by significant numbers of liver MNC, and autoreactive $\mathrm{T}$ cells that recognise CD1c and CD1d and release inflammatory cytokines are abundant in normal and tumour-bearing human liver. We also have found that $\mathrm{CD} 1 \mathrm{~b}$ is expressed in MNC from tumour-bearing but not normal liver. 


\section{Materials and methods}

Tissue specimens

Wedge liver biopsies (50-100 $\mathrm{mg}$ ) were obtained from 14 healthy donor organs at the time of liver transplantation. Liver biochemistry and histology were normal in all cases. Liver tissue was also obtained from 15 patients undergoing resection for hepatic metastases of colonic origin. Wedge biopsies from tumour-bearing tissue were taken approximately $10 \mathrm{~cm}$ from the tumour margin and appeared histologically normal. All organ donors and patients were negative for hepatitis $\mathrm{A}, \mathrm{B}, \mathrm{C}, \delta$ and $\mathrm{E}$ viruses. Blood samples were obtained from seven healthy donors. Ethical approval for this study was obtained from the Research and Ethics Committee at St. Vincent's University Hospital, Dublin, Ireland.

Preparation of peripheral blood and liver MNC

Mononuclear cells were prepared from anti-coagulated whole blood by Lymphoprep (Nycomed, Oslo, Norway) density gradient centrifugation. Single liver cell suspensions, which contain MNC and residual parenchymal cells, were prepared as previously described [43]. $\mathrm{CD}^{+}$cells were isolated from fresh hepatic and peripheral MNC preparations by positive selection using monoclonal antibody (mAb)-coated magnetic beads (Miltenyi Biotec, Bergisch Gladbach, Germany). The purity of isolated fractions was assessed by flow cytometry and only preparations with purities of $95 \%$ or greater were used for functional studies.

\section{Analysis of CD1 mRNA}

RNA was isolated from snap frozen liver specimens using the Rneasy Mini Kit (Qiagen, Crawley, UK) and reverse transcribed into cDNA using Superscript II (Promega, Madison, WI). Polymerase chain reaction (PCR) amplification of CD1a, CD1b, CD1c and CD1d was carried out in separate $25 \mu \mathrm{l}$ reactions containing $1 \mu \mathrm{lDNA}$ with the following oligonucleotide primer pairs (forward and reverse) [29, 54]:

CD1a, ATGCTGTTTTTGCTACTTCCATTGTTA and CGTGGGCAGGTGTCACTGAGAAG,

CD1b, ATGCTGCTGCTGCCATTTCAACTGT

TA and GGGCAGGTTTCATAGAGGAGAAT

TC,

CD1c, ATGCTGTTTCTGCAGTTTCTGCTGCT

A and CTGTTTCTGTGACGCCTTCATACTG,
CD1d, GCTCCACCAGGACAAGTGGACGAG and GGAGGTAAAGCCCACAATGAGGAG.

These primers produced products of 530, 528, 529 and $535 \mathrm{bp}$, respectively. Thermocycling conditions consisted of an initial incubation at $94^{\circ} \mathrm{C}$ for $10 \mathrm{~min}$ to activate the polymerase enzyme (AmpliTaq Gold, Gibco BRL Life Technologies, Paisley, UK) followed by 30 cycles consisting of $1 \mathrm{~min}$ at $94^{\circ} \mathrm{C}, 2 \mathrm{~min}$ at $60^{\circ} \mathrm{C}$, and $2 \mathrm{~min}$ at $72^{\circ} \mathrm{C}$. As a control, PCR was performed on all samples using primers specific for the housekeeping gene glyceraldehyde phosphate dehydrogenase (GAPDH), GCCTCAAGATCATCAGCAA and CCAGCGTCAAAGGTGGAG.

\section{Antibodies and flow cytometry}

The expression of $\mathrm{CD} 1$ protein by liver cells in single cell suspensions was determined by flow cytometry using the unconjugated mAbs, 10H3.9.3 (CD1a), BCD1b3 (CD1b), F10/21A3 (CD1c) and CD1d51 (CD1d), which we have previously generated [20, 26]. Briefly, $10^{5}$ cells were incubated with $0.2 \mu$ g antibody for $20 \mathrm{~min}$ at $4^{\circ} \mathrm{C}$ and washed twice in PBA buffer (PBS containing $1 \%$ bovine serum albumin and $0.02 \%$ sodium azide). The cells were then incubated for $20 \mathrm{~min}$ at $4^{\circ} \mathrm{C}$ with $5 \mu \mathrm{l}$ of a $1 / 5$ dilution of rabbit antimouse immunoglobulin conjugated to fluorescein isothiocyanate (Dako, Cambridge, UK), washed as before, and incubated for $15 \mathrm{~min}$ at $4^{\circ} \mathrm{C}$ with $50 \mu \mathrm{l}$ of a $1 / 25$ dilution of filtered normal mouse serum (Vector Laboratories, Peterborough, UK). Cells were washed twice in PBA buffer and analysed immediately on a FACScan flow cytometer (Becton Dickinson, Oxford, UK). The expression of CD1 by lymphocytes and nonlymphocytes within MNC was assessed by electronic gating of the lymphocytes which display lower forward and side scatter. C1R cell lines transfected with the individual CD1 isoforms [19] were used as positive controls for $\mathrm{mAb}$ staining. Intracellular $\mathrm{CD} 1$ was detected by fixing cells with $4 \%$ paraformaldehyde and permeabilising them with $0.2 \%$ saponin (Sigma-Aldrich, Dublin, Ireland) before adding the anti-CD1 mAbs [16].

Assessment of hepatic $\mathrm{T}$ cell reactivity against $\mathrm{CD} 1$ in vitro

Purified hepatic or peripheral $\mathrm{CD}^{+}$cells $\left(6 \times 10^{4}\right.$ cells) were cultured in triplicate in medium alone, with phytohaemagglutinin, or with equal numbers of mock-transfected $\mathrm{C} 1 \mathrm{R}$ cells or C1R cells transfected with CD1a, CD1b, CD1c or CD1d [19] in complete 
RPMI-1640 medium containing $10 \%$ foetal calf serum, $20 \mathrm{IU} / \mathrm{ml}$ recombinant human IL-2 (National Cancer Institute-Frederick Research Foundation Biological Resources Branch) and $1 \mathrm{ng} / \mathrm{ml}$ phorbol myristate acetate (Sigma-Aldrich) in a final volume of $250 \mu \mathrm{l}$. For CD1 blocking experiments, the C1R-CD1 transfectants were first mixed with $1.0 \mu \mathrm{g} / \mathrm{ml}$ of the relevant $\mathrm{mAb}$ or isotype matched control antibody before addition of $\mathrm{T}$ cells. After $48-72 \mathrm{~h}$ supernatants were removed for analysis of IFN- $\gamma$ and IL-4 production by enzymelinked immunosorbent assays (ELISA) using mAb pairs obtained from R\&D Systems (Abingdon, UK). The invariant NKT cell line, LPK 89 [23], was used as a positive control for in vitro CD1d-reactivity.

\section{Statistical analyses}

Mean fluorescence intensities and cytokine levels were compared using the unpaired Student's $t$ test and $P$ values of $<0.05$ were considered significant.

\section{Results}

Expression of CD1 mRNA in human liver

PCR amplification of reverse transcribed mRNA was used to analyse the presence of CD1a, CD1b, CD1c and CD1d transcripts in normal $(n=14)$ and tumourbearing $(n=15)$ liver samples. Representative results for four normal and three tumour-bearing liver samples are shown in Fig. 1. CD1a transcripts were found to be variably present in all liver samples examined. CD1b, CD1c and CD1d mRNA were found to be abundant in whole liver samples from both normal and tumour-bearing tissue (Fig. 1).

\section{Expression of CD1 protein by human liver MNC}

The expression of CD1a, CD1b, CD1c and CD1d protein isoforms by freshly isolated hepatic MNC was examined by $\mathrm{mAb}$ staining and flow cytometry. Mocktransfected C1R cells and C1R cells transfected with CD1a, CD1b, CD1c or CD1d were used as positive controls for mAb staining (Fig. 2a). While CD1a, b and $\mathrm{c}$ were not expressed at the cell surface of MNC from five normal liver samples tested, CD1d was weakly expressed (Fig. 2b, c). No induction or reduction of cell surface expression of any of the CD1 isoforms was detected in five samples of tumour-bearing liver cells (Fig. 2c).

To detect whether CD1 isoforms are expressed intracellularly, cell suspensions from five normal livers

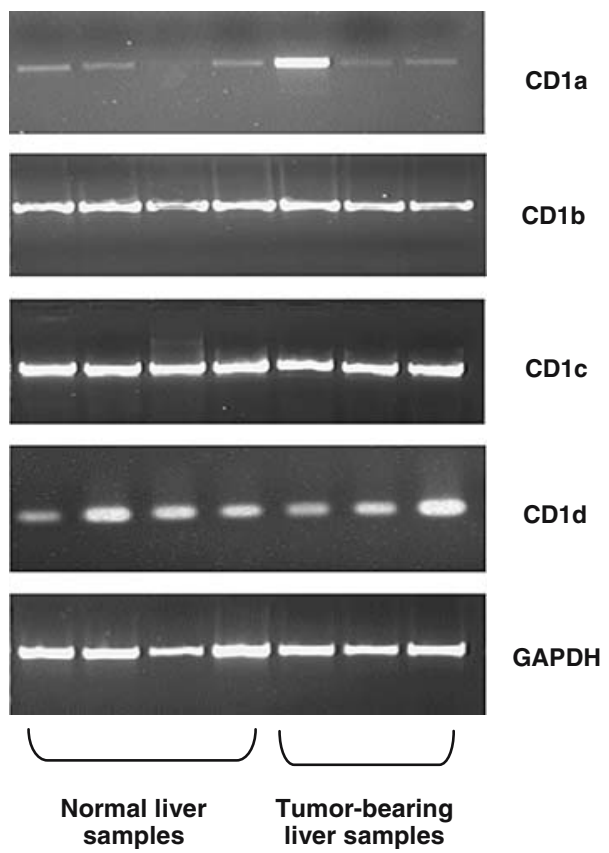

Fig. 1 Expression of CD1a, CD1b, CD1c and CD1d mRNA in whole human liver samples. Reverse transcription-PCR analysis of CD1a-d and, as a control, glyceraldehyde phosphate dehydrogenase (GAPDH) expression in four normal and three representative tumour-bearing liver samples. Results are representative of 14 normal and 15 tumour-bearing liver samples

were permeabilised with saponin before $\mathrm{mAb}$ staining and analysed by flow cytometry (Fig. 2b). In all samples from healthy livers CD1a and CD1b expression was undetectable following permeabilisation, but significant CD1c and CD1d staining was seen (Fig. 2d). Separate analysis of the lymphocyte and non-lymphocytes within the liver cell suspensions by electronic gating indicated that both fractions stained positive for CD1c and CD1d (data not shown). Analysis of MNC from five tumour-bearing livers showed low but significantly increased intracellular expression of CD1b $(P=0.002)$ and slightly elevated cell-surface and intracellular expression of CD1d. The changes in CD1d expression were not significant (Fig. 2c, d).

Hepatic $\mathrm{T}$ cell responses to $\mathrm{CD} 1$ isoforms

Since CD1 isoforms are expressed in human liver, we next determined whether CD1-reactive $\mathrm{T}$ cells were detectable in liver. IFN- $\gamma$ and IL- 4 secretion by $\mathrm{CD}^{+}$ cells purified from five normal donor livers in response to mock-transfected $\mathrm{C} 1 \mathrm{R}$ cells or $\mathrm{C} 1 \mathrm{R}$ cells transfected with CD1a, CD1b, CD1c or CD1d was measured by ELISA. The levels of cell-surface CD1 expression by the C1R cells used as stimulators were shown by flow cytometry to be comparable for all CD1 isoforms (Fig. 2a). Figure 3a shows that minimal responses, 
Fig. 2 Expression of CD1a, CD1b, CD1c and CD1d protein by freshly isolated human liver mononuclear cells (MNC). a Flow cytometric evaluation of the expression of transfected CD1a, CD1b, CD1c and CD1d by the C1R cells used in the present study. b Representative flow cytometry histograms showing cellsurface (top) and intracellular (bottom) CD1a-d expression by human hepatic MNC.

Mean fluorescence intensities of cell-surface (c) and intracellular (d) staining of MNC from five histologically normal liver samples (open circles) and five liver samples taken from patients with hepatic malignancy (closed circles) with mAbs specific for CD1a-d after subtraction of mean fluorescence intensities obtained using isotypematched antibody controls a
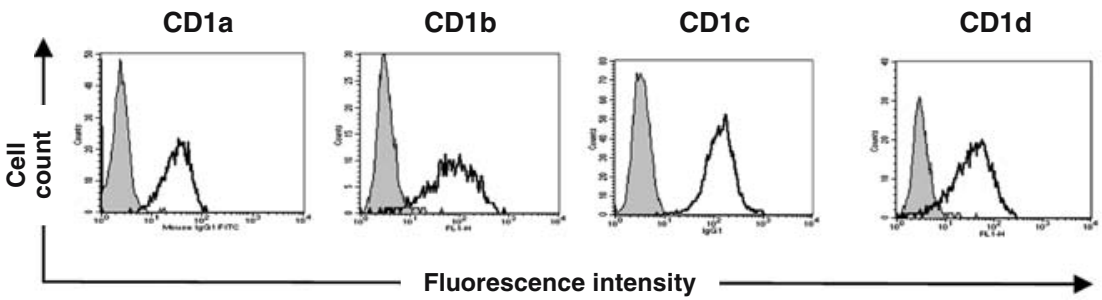

b
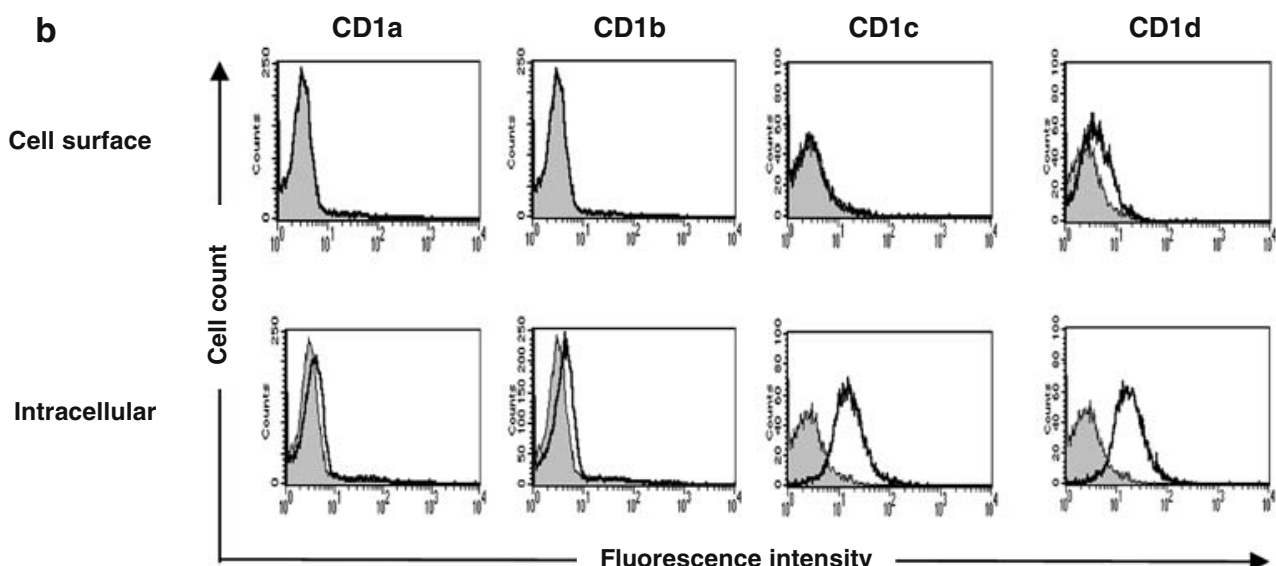

Fluorescence intensity

C

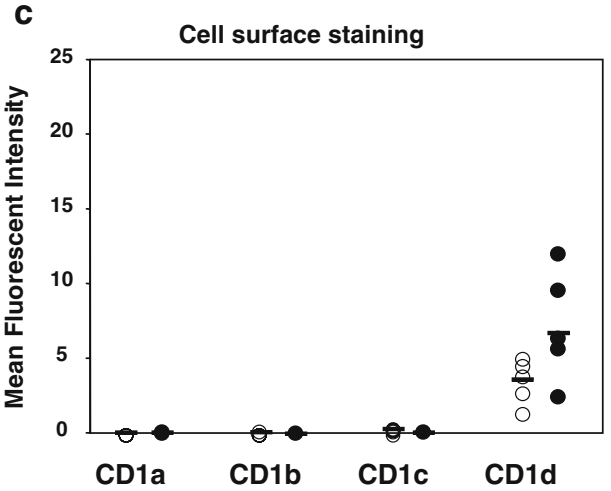

comparable to alloresponses, were obtained using the CD1a and CD1b transfectants as stimulators in IFN- $\gamma$ and IL-4 assays. In contrast, hepatic $\mathrm{CD}^{+}$cells from normal liver responded to CD1c and CD1d by releasing IFN- $\gamma$ (means $2.37 \mathrm{ng} / \mathrm{ml}$ for CD1c and $4.76 \mathrm{ng} / \mathrm{ml}$ for CD1d). In all five normal samples tested, the CD1d-specific IFN- $\gamma$ response was comparable to the response to mitogen stimulation of the same cells $(3.94 \mathrm{ng} / \mathrm{ml})$ and CD1d stimulation of the human blood-derived invariant NKT cell line, LPK.89. These IFN- $\gamma$ levels are significantly higher than those obtained when similar numbers of peripheral blood $\mathrm{CD}^{+}$cells were similarly stimulated. Means of 0.17 , $0.13,0.18$ and $0.3 \mathrm{ng} / \mathrm{ml} \mathrm{IFN-} \gamma(n=3$ samples) were released by peripheral blood T cells in response to C1R cells expressing transfected CD1a, CD1b, CD1c and CD1d, respectively (Fig. 3a, upper central panel).
No IL-4 was released by hepatic $\mathrm{CD}^{+}$cells stimulated with any of the CD1 isoforms. This contrasts with our observations of IL-4 production (mean $121 \mathrm{pg} / \mathrm{ml}$ ) by hepatic $\mathrm{CD}^{+}$cells in response to phytohaemagglutinin stimulation, and by the invariant NKT cell line, LPK.89 (436 pg/ml), in response to CD1d. IL-4 release by $\mathrm{CD}^{+} \mathrm{PBMC}$ in response to $\mathrm{CD} 1$ was not investigated, but undetectable levels of another Th2 cytokine, IL-13, were released peripheral $\mathrm{T}$ cells in response to each CD1 isoform (data not shown).

Conformational CD1-specific and control $\mathrm{mAb}$ blocking experiments were used to determine the specificity of the interaction between hepatic $\mathrm{CD}^{+}$ cells and CD1c and CD1d and to test whether responses were specific for intact $\mathrm{CD} 1$ rather than CD1 peptides presented indirectly by MHC molecules (Fig. 3b). Incubation of the transfectants with 
Fig. 3 Human hepatic T cell reactivity against $C D 1 \mathrm{a}$, CD1b, CD1c and CD1d. a IFN- $\gamma$ (top) and IL-4 (bottom) release by hepatic $\mathrm{CD}^{+}$cells (left), peripheral blood $\mathrm{CD}^{+}$ cells (centre) and the CD1drestricted NKT cell line, LPK.89 (right) in response to mock-transfected C1R cells, C1R cells transfected with CD1a, CD1b, CD1c or CD1d, or phytohaemagglutinin (PHA). b IFN- $\gamma$ release by hepatic $\mathrm{CD}^{+}$cells in response to mock-transfected $\mathrm{C} 1 \mathrm{R}$ cells, C1R cells transfected with CD1c or CD1d in the presence of F10/21A3 (anti-CD1c mAb), CD1d51 (anti-CD1d mAb), or isotype-matched control antibody. Results are means of five normal liver and seven blood samples
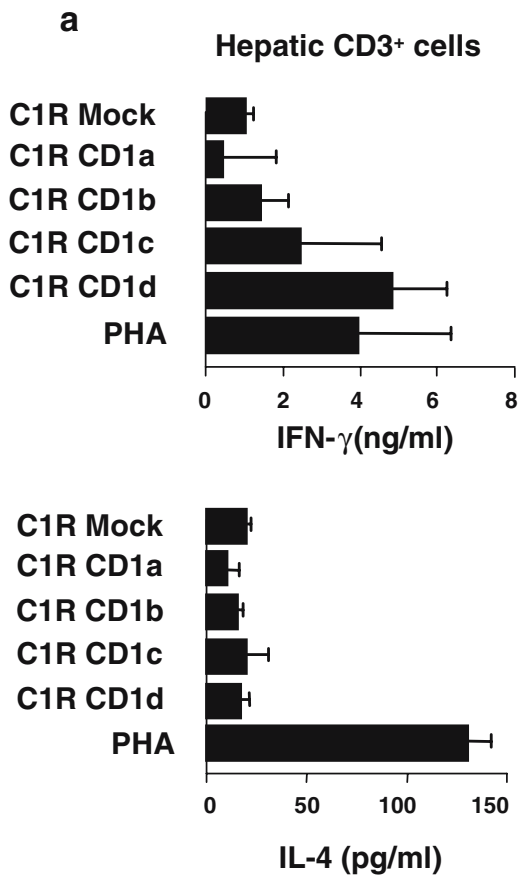

b

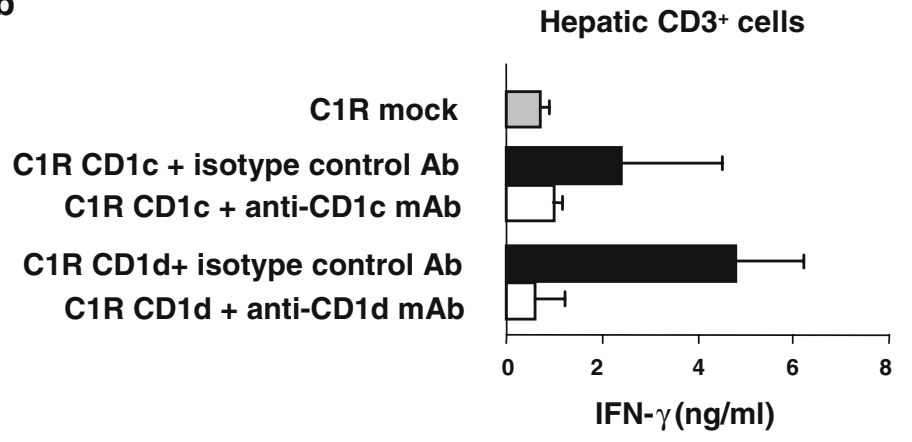

NKT cells (LPK.89)
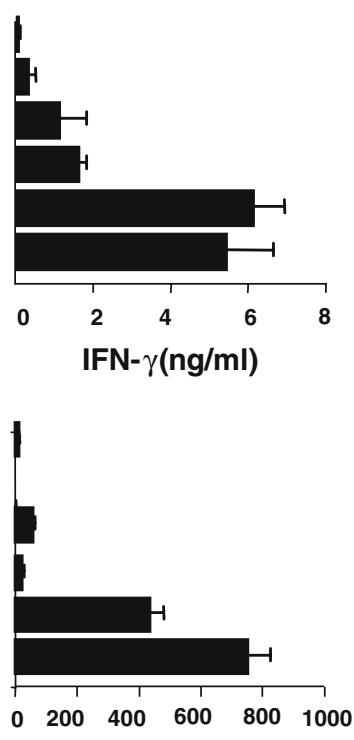

IL-4 (pg/ml)
$0.2 \mu \mathrm{g} / \mathrm{ml}$ of anti-CD1c (F10/21A3) or anti-CD1d (CD1d51) mAbs prior to addition of $\mathrm{T}$ cells almost completely blocked CD1-induced IFN- $\gamma$ production by hepatic $\mathrm{CD} 3^{+}$cells. Therefore, the $\mathrm{T}$ cell reactivity against C1R cells expressing CD1c or CD1d is CD1specific and not a result of recognition of the peptide fragments derived from these molecules presented by MHC molecules.

\section{CD1-reactive $\mathrm{T}$ cells in tumour-bearing liver}

IFN- $\gamma$ and IL-4 secretion by $\mathrm{CD}^{+}$cells purified from five tumour-bearing liver specimens in response to mock-transfected $\mathrm{C} 1 \mathrm{R}$ cells and $\mathrm{C} 1 \mathrm{R}$ cells transfected with CD1a, CD1b, CD1c and CD1d was also measured by ELISA. Figure 4 illustrates that, like normal liver, tumour-bearing liver also contains IFN- $\gamma$-producing $\mathrm{T}$ cells that are reactive against CD1c and CD1d, but neither CD1a nor CD1b. The levels of IFN- $\gamma$ produced by hepatic $\mathrm{T}$ cells in response to $\mathrm{CD} 1 \mathrm{c}$ were similar in tumour-bearing (means $2.9 \mathrm{ng} / \mathrm{ml}$, range $1.28-5.64 \mathrm{ng} /$ $\mathrm{ml})$ and normal $(2.37 \mathrm{ng} / \mathrm{ml}$, range $1.07-4.13 \mathrm{ng} / \mathrm{ml})$ livers. IFN- $\gamma$ production by hepatic $\mathrm{T}$ cells in response to CD1d stimulation appeared to be slightly lower using cells derived from tumour-bearing tissue $(3.2 \mathrm{ng} / \mathrm{ml}$, range 1.11-8.64) compared with normal hepatic $\mathrm{T}$ cells $(4.8 \mathrm{ng} / \mathrm{ml}$, range $3.04-8.21 \mathrm{ng} / \mathrm{ml})$, but this difference was not significant $(P>0.05)$. As with normal hepatic $\mathrm{CD}^{+}$cells, $\mathrm{T}$ cells derived from tumour-bearing livers did not produce measurable IL-4 in response to CD1 stimulation but were capable of comparable IL-4 secretion upon mitogenic stimulation (Fig. 4).

\section{Discussion}

Murine liver contains large numbers of CD1d-restricted invariant NKT cells, with up to $50 \%$ of intrahepatic 


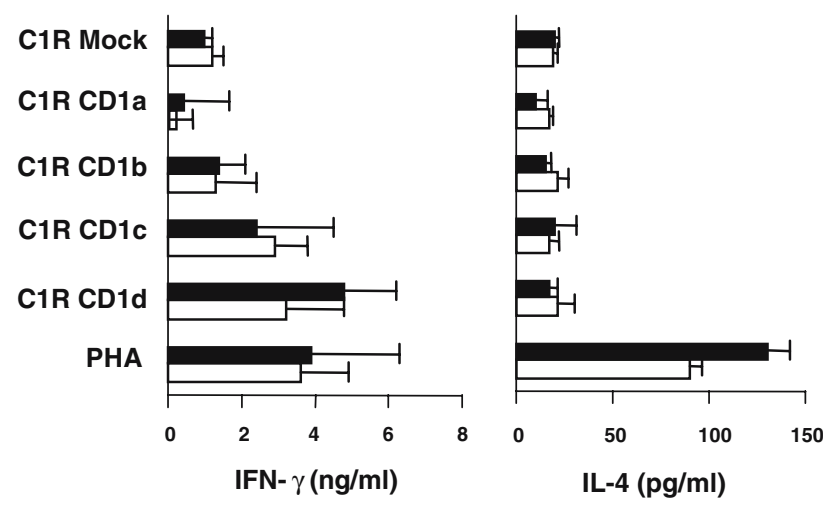

\section{Normal Liver \\ Tumor-bearing Liver}

Fig. 4 CD1 reactivity of hepatic T cells from normal donors and patients with hepatic malignancy. IFN- $\gamma$ (left) and IL-4 (right) release by hepatic $\mathrm{CD}^{+}$cells from donor organs used for transplantation and resected liver tissue from patients with hepatic malignancy in response to mock-transfected $\mathrm{C} 1 \mathrm{R}$ cells, $\mathrm{C} 1 \mathrm{R}$ cells transfected with CD1a, CD1b, CD1c or CD1d, or PHA. Results are means of five normal and five tumour liver specimens

lymphocytes expressing NK1.1 and invariant V $\alpha 14 \mathrm{~J} \alpha 18$ TCR $\alpha$-chains [4, 18]. Invariant NKT cells display potent cytolytic activity and the rapid secretion of Th1 (IFN- $\gamma$ ), Th2 (IL-4 and IL-13) and immunosuppressive (IL-10) cytokines, making them potential regulators of adaptive immune responses $[4,11,19,51]$. They can play key roles in immune defence against viruses, bacteria, fungi, parasites and tumours and the prevention of autoimmune disease in various mouse models [7, 28]. NKT cells are therefore under scrutiny as potential targets for immunotherapy for cancer, and multiple clinical trials using $\alpha \mathrm{GC}$ are under way [25, 42].

In contrast to murine NKT cells, the roles of CD1drestricted $\mathrm{T}$ cells in hepatic immunoregulation and anti-tumour immunity in the human are less clear. Humans have invariant CD1d-restricted NKT cells expressing V $\alpha 24 \mathrm{~J} \alpha 18$ TCR $\alpha$-chains, with similar antigen specificities and functional activities to murine invariant NKT cells [19], but which are found in significantly lower numbers in liver $(\sim 0.5 \%$ of $\mathrm{T}$ cells $)$ and blood $(\sim 0.02 \%)$ compared to their murine counterparts [30, 33, 38]. However, the human liver contains large numbers of $\mathrm{T}$ cells with diverse TCRs that express NK cell receptors and display NK-like functional activities [16, 43]. It is possible that hepatic T cells include cells that use non-invariant TCRs to recognise CD1d or the other CD1 isotypes, CD1a-c, which are not found in mice. We have addressed this hypothesis by examining CD1 isotype expression and
T cell reactivity to $\mathrm{CD} 1 \mathrm{a}, \mathrm{CD} 1 \mathrm{~b}, \mathrm{CD} 1 \mathrm{c}$ and $\mathrm{CD} 1 \mathrm{~d}$ in healthy and tumour-bearing human livers.

We report that CD1a, CD1b, CD1c and CD1d mRNA were detectable in all adult human liver specimens tested. CD1a and CD1b proteins were not detected at the cell surface or within hepatic MNC from five normal livers tested. The finding of CD1a and CD1b mRNA but not protein expression suggests that these CD1 isoforms may be expressed by other liver cells. CD1b was expressed intracellularly in five of five tumour-bearing livers, suggesting that CD1b-restricted $\mathrm{T}$ cells may play a role in immunity against tumours. CD1c and CD1d were expressed at very low levels at the cell surface, but were found at an intracellular location in significant numbers of liver MNC from all samples tested, including lymphocytes and non-lymphocytes. Previous work has shown that CD1d is most prominently expressed by intestinal epithelial cells $[2,6]$, thymocytes and haematopoietic-derived cells $[9,20]$ but it has also been reported to be expressed inside hepatocytes in mice $[6,39]$ and by hepatocytes, cholangiocytes and hepatic MNC in humans with inflammatory diseases of the liver $[1,10,17,36,57]$. While CD1d expression does not appear to be induced by individual cytokines or growth factors [52], the intracellular location of CD1d in normal human liver, found in the present study, suggests that MNC surface expression of CD1d may be rapidly induced by translocation to the cell surface. Future studies are required to determine what signals may mediate this process. We have also detected intracellular, but not cell surface, expression of $\mathrm{CD} 1 \mathrm{c}$ by liver MNC, suggesting that this CD1 isoform may also be similarly translocated to the cell surface in response to as yet unknown signals. CD1c is known to be expressed by dendritic cells and B cells [7, 46], which are abundant in liver.

In addition to our finding that $\mathrm{CD} 1 \mathrm{c}$ and $\mathrm{CD} 1 \mathrm{~d}$ are the only $\mathrm{CD} 1$ isoforms that show significant expression in human liver $\mathrm{MNC}$, we found that hepatic $\mathrm{T}$ cell reactivity against $\mathrm{CD} 1$, expressed by $\mathrm{C} 1 \mathrm{R}$ cells, was limited to CD1c and CD1d. Stimulation of T cells from a total of ten liver samples with C1R cells expressing CD1c or CD1d resulted in means of 13-fold and 16-fold more IFN- $\gamma$ release, respectively, than for stimulation of similar numbers of peripheral blood $\mathrm{T}$ cells. Little or no IFN- $\gamma$ was released by hepatic $\mathrm{T}$ cells in response to $\mathrm{CD} 1 \mathrm{a}$ and CD1b. Although it is possible that the transfected C1R cells used in the present study have altered antigen-presenting properties compared to natural antigen-presenting cells, our results suggest that hepatic $\mathrm{T}$ cell recognition of $\mathrm{CD} 1$ is limited to $\mathrm{CD} 1 \mathrm{c}$ and CD1d. CD1d-reactivity of human hepatic T cells from patients with chronic hepatitis $\mathrm{C}$ virus infection 
has also been demonstrated $[1,17,21]$. This reactivity is presumably mediated, in part, by invariant V $\alpha 24 \mathrm{~V} \beta 11^{+}$NKT cells $[30,33,38]$ but invariant NKT cells were found to account for only $0.5 \%$ of hepatic $\mathrm{T}$ cells [33]. Their low numbers in human liver despite strong CD1d reactivity suggests that other non-invariant CD1d-restricted T cells may predominate. CD1drestricted NKT cells with diverse TCRs have been described in mice and humans [3, 21, 22, 44] and it is thought that invariant and non-invariant NKT cells sample antigens in different endosomal compartments [12]. Future work is required to determine which T cell subpopulations recognise $\mathrm{CD} 1 \mathrm{~d}$; however, previous studies have shown that the human liver harbours several subsets of $\mathrm{T}$ cells that, like invariant NKT cells, express NK receptors and mediate NK-like cytotoxicity $[16,32,33,43]$. Recognition of $\alpha \mathrm{GC}$ is primarily, although not exclusively, restricted to invariant NKT cells $[5,24,30]$; therefore, therapies based on $\alpha \mathrm{GC}$ would be less efficacious in humans compared to mouse models.

Murine and human invariant NKT cells are notable for their ability to rapidly secrete IFN- $\gamma$ and IL-4 upon stimulation with CD1d $[4,11,19,51]$. The production of these cytokines, which have opposing effects of Th cell differentiation, implicates invariant NKT cells as drivers and regulators of adaptive immune responses. However, we have found that human hepatic $\mathrm{T}$ cells specifically release IFN- $\gamma$ only in response to CD1dexpressing C1R cells. The lack of IL-4 production in this in vitro system is consistent with previous findings on human hepatic CD1d-reactive and V $\alpha 24 \mathrm{~V} \beta 11^{+} \mathrm{T}$ cells $[21,33]$ but contrasts with those on CD1d-reactive T cells from human blood [19] and bone marrow [22]. These differences suggest that CD1d-reactive $\mathrm{T}$ cells may have different immunoregulatory roles in different tissues.

Our observation that human hepatic $\mathrm{T}$ cells exhibit significant reactivity against $\mathrm{CD} 1 \mathrm{c}$ indicates the presence of a second lineage of potential lipid-recognizing $\mathrm{T}$ cells in the human liver. These cells also released IFN- $\gamma$, but not IL-4, in response to stimulation. In the absence of identifiable markers of CD1c-restricted cells, we do not know which $\mathrm{T}$ cell populations recognise CD1c, but subpopulations of $\gamma \delta$ T cells, most notably $\mathrm{V} \delta 1^{+} \mathrm{T}$ cells, are known to be CD1c-restricted [37, 45,53 ]. We have reported [32] that human liver is a rich source of $\gamma \delta \mathrm{T}$ cells, which comprise $\sim 7 \%$ of hepatic $\mathrm{T}$ cells with significant numbers expressing $\mathrm{V} \delta 1, \mathrm{~V} \delta 2$ and V $\delta 3$ TCR chains. It is possible that these cells contribute to the CD1c-reactivity. However, not all CD1c-reactive T cells are $\gamma \delta$ T cells and several distinct populations of $\alpha \beta$ T cells can also recognise CD1c [40, 47]; therefore, it is likely that the repertoire of hepatic CD1c-reactive T cells is heterogeneous.

CD1d-restricted NKT cells play key roles in antitumour defence in mice. Injection of mice with either IL-12 or $\alpha \mathrm{GC}$ results in tumour rejection by a mechanism that is dependent upon IFN- $\gamma$ production and/ or anti-tumour cytotoxicity by NKT cells [41, 50]. Furthermore, mice deficient in CD1d or NKT cells fail to mediate IL-12-induced rejection of tumours [14]. Numerical and functional deficiencies of NKT cells have been reported in humans with tumours $[15,33,55$, 59]; therefore, we compared CD1 expression and T cell reactivity against $\mathrm{CD} 1$ in liver samples from normal donors and uninvolved liver tissue from patients with metastatic liver disease. We found no significant differences in CD1a, CD1c or CD1d mRNA or protein expression and no differences in hepatic $\mathrm{T}$ cell reactivity against these molecules in the two groups. We found a significant upregulation of intracellular CD1b expression by MNC from tumour-bearing livers compared with healthy livers. We observed a non-significant trend towards less CD1d- and more CD1c-reactivity in tumour-bearing livers compared with normal controls, which mirrors reductions of $\mathrm{V} \alpha 24^{+} \mathrm{V} \beta 11^{+}$NKT cells and expansions of $\mathrm{V} \delta 1^{+} \mathrm{T}$ cells which we have seen in patients with hepatic malignancy $[32,33]$.

Our data provide evidence that the adult human liver is a site of accumulation of autoreactive $\mathrm{T}$ cells that respond to $\mathrm{CD} 1 \mathrm{c}$ or CD1d by releasing IFN $-\gamma$. T cells that recognise CD1c and CD1d have been shown to play immunostimulatory roles at early stages of immune responses by responding to self-lipids presented by immature dendritic cells. Upon exposure to microbial products, such as lipopolysaccharide, dendritic cells secrete proinflammatory cytokines (IL-12) that amplify weak responses of invariant NKT cells to CD1d-presented self-antigens [8]. Thus NKT cells can become activated in many different microbial infections, resulting in the release of chemokines and cytokines that promote recruitment and activation of macrophages, NK cells, T cells and B cells. CD1a-drestricted $\mathrm{T}$ cells can also reciprocally induce maturation of dendritic cells and their release of IL-12 [35, 37, $56,58]$. The liver is notable for its ability to induce immunological tolerance to dietary antigens entering from the hepatic portal vein [13] despite having multiple lymphocyte populations that display potent Th1 activities ex vivo [16, 43]. Autoreactive CD1-restricted $\mathrm{T}$ cells could provide mechanisms whereby active immunity can be rapidly induced within this tolerogenic environment, by maintaining a low level of autoreactivity that can be upregulated in response to pathogens. 
Acknowledgments We are grateful to our surgical colleagues, Gerry McEntee, Oscar Traynor, Raghu Varadarajan, Justin Geoghegan and the liver transplant coordinators, Sheila O'Toole, Aoife Coffey and Jennifer Fleming, at St. Vincent's University Hospital for assistance in obtaining liver biopsy samples and to Laura Madrigal-Estebas and Lucy Golden-Mason for helpful discussions. This work was supported by grants awarded by the Irish Health Research Board, Science Foundation Ireland and the National Institute of Health (DK066917)

\section{References}

1. Agrati C, Martini F, Nisii C, Oliva A, D'Offizi G, Narciso P, Nardicci R, Piacantini M, Dieli F, Pucillo LP, Poccia F (2005). CD1d expression by hepatocytes is a main restriction element for intrahepatic T-cell recognition. J Biol Regul Homeost Agents 19:41-48

2. Balk SP, Burke S, Polischuk JE, Frantz ME, Yang L, Porcelli S, Colgan SP, Blumberg RS (1994) $\beta_{2}$-microglobulin-independent MHC class Ib molecule expressed by human intestinal epithelium. Science 265:259-262

3. Behar SM, Podrebarac TA, Roy CJ, Wang CR, Brenner MB (1999) Diverse TCRs recognize murine CD1. J Immunol 162:161-167

4. Bendelac A, Rivera MN, Park SH, Roark JH (1997) Mouse CD1-specific NK1 T cells: development, specificity, and function. Annu Rev Immunol 15:535-562

5. Benlagha K, Weiss A, Beavis A, Teyton L, Bendelac A (2000) In vivo identification of glycolipid antigen-specific $T$ cells using fluorescent CD1d tetramers. J Exp Med 191:18951903

6. Bleicher PA, Balk SP, Hagen SJ, Blumberg RS, Flotte TJ, Terhorst C (1990) Expression of murine CD1 on gastrointestinal epithelium. Science 250:679-682

7. Brigl M, Brenner MB (2004) CD1: antigen presentation and T cell function. Annu Rev Immunol 22:817-890

8. Brigl M, Bry L, Kent SC, Gumperz JE, Brenner MB (2003) Mechanism of CD1d-restricted natural killer T cell activation during microbial infection. Nat Immunol 4:1230-1237

9. Brossay L, Jullien D, Cardell S, Sydora BC, Burdin N, Modlin RL, Kronenberg M (1997) Mouse CD1 is mainly expressed on hemopoietic-derived cells. J Immunol 159:1216-1224

10. Canchis PW, Bhan AK, Landau SB, Yang L, Balk SP, Blumberg RS (1993) Tissue distribution of the non-polymorphic major histocompatibility complex class I-like molecule, CD1d. Immunology 80:561-565

11. Chen H, Paul WE (1997) Cultured NK1.1 ${ }^{+} \mathrm{CD} 4^{+} \mathrm{T}$ cells produce large amounts of IL-4 and IFN- $\gamma$ upon activation by anti-CD3 or CD1. J Immunol 159:2240-2249

12. Chiu YH, Jayawardena J, Weiss A, Lee D, Park SH, DautryVarsat A, Bendelac A (1999) Distinct subsets of CD1drestricted $\mathrm{T}$ cells recognize self-antigens loaded in different cellular compartments. J Exp Med 189:103-110

13. Crispe IN (2003) Hepatic T cells and liver tolerance. Nat Rev Immunol 3:51-62

14. Cui J, Shin T, Kawano T, Sato H, Kondo E, Toura I, Kaneko Y, Koseki H, Kanno M, Taniguchi M (1997) Requirement for Va14 NKT cells in IL-12-mediated rejection of tumours. Science 278:1623-1626

15. Dhodapkar MV, Geller MD, Chang DH, Shimizu K, Fujii S, Dhodapkar KM, Krasovsky J (2003) A reversible defect in natural killer $\mathrm{T}$ cell function characterizes the progression of premalignant to malignant multiple myeloma. J Exp Med 197:1667-1676
16. Doherty DG, Norris S, Madrigal-Estebas L, McEntee G, Traynor O, Hegarty JE, O'Farrelly C (1999) The human liver contains multiple populations of $\mathrm{NK}$ cells, $\mathrm{T}$ cells, and $\mathrm{CD}^{+} \mathrm{CD}^{+} 6^{+}$natural $\mathrm{T}$ cells with distinct cytotoxic activities and Th1, Th2, and Th0 cytokine secretion patterns. J Immunol 163:2314-2321

17. Durante-Mangoni E, Wang R, Shaulov A, He Q, Nasser I, Afdhal N, Koziel MJ, Exley MA (2004) Hepatic CD1d expression in hepatitis $\mathrm{C}$ virus infection and recognition by resident proinflammatory CD1d-reactive $\mathrm{T}$ cells. $\mathrm{J}$ Immunol 173:2159-2166

18. Eberl G, Lees R, Smiley ST, Taniguchi M, Grusby MJ, MacDonald HR (1999) Tissue-specific segregation of CD1ddependent and CD1d-independent NK T cells. J Immunol 162:6410-6419

19. Exley M, Garcia J, Balk SP, Porcelli S (1997). Requirements for CD1d recognition by human invariant $\mathrm{V} \alpha 24^{+} \mathrm{CD} 4^{-} \mathrm{CD} 8^{-}$ T cells. J Exp Med 186:109-120

20. Exley M, Garcia J, Wilson SB, Spada F, Gardes D, Tahir SM, Patton KT, Blumberg RS, Porcelli S, Chott A, Balk SP (2000) CD1d structure and regulation on human thymocytes, peripheral blood $\mathrm{T}$ cells, B cells and monocytes. Immunology 100:37-47

21. Exley MA, He Q, Cheng O, Wang RJ, Cheney CP, Balk SP, Koziel MJ (2002) Cutting edge: Compartmentalization of Th1-like noninvariant CD1d-reactive $\mathrm{T}$ cells in hepatitis C virus-infected liver. J Immunol 168:1519-1523

22. Exley MA, Tahir SM, Cheng O, Shaulov A, Joyce R, Avigan D, Sackstein R, Balk SP (2001) A major fraction of human bone marrow lymphocytes are Th2-like CD1d-reactive $\mathrm{T}$ cells that can suppress mixed lymphocyte responses. J Immunol 167:5531-5534

23. Exley MA, Wilson SB, Balk S (2002) Isolation and functional use of human NKT cells. In: Coligan JE, Kruisbeek AM, Margulies DH, Shevach EM, Strober W (eds) Current protocols in immunology. Wiley, London, pp 14.11.1-14.11.13

24. Gadola SD, Dulphy N, Salio M, Cerundolo V (2002) V $\alpha 24-$ $\mathrm{J} \alpha \mathrm{Q}$-independent, CD1d-restricted recognition of $\alpha$-galactosylceramide by human $\mathrm{CD}^{+}$and $\mathrm{CD} 8 \alpha \beta^{+} \mathrm{T}$ lymphocytes. J Immunol 168:5514-5520

25. Giaccone G, Punt CJ, Ando Y, Ruijter R, Nishi N, Peters M, von Blomberg BM, Scheper RJ, van der Vliet $\mathrm{HJ}$, van den Eertwegh AJ, Roelvink M, Beijnen J, Zwierzina H, Pinedo HM (2002) A phase I study of the natural killer T-cell ligand $\alpha$-galactosylceramide (KRN7000) in patients with solid tumours. Clin Cancer Res 8:3702-3709

26. Grant EP, Degano M, Rosat JP, Stenger S, Modlin RL, Wilson IA, Porcelli SA, Brenner MB (1999) Molecular recognition of lipid antigens by T cell receptors. J Exp Med 189:195-205

27. Gumperz JE, Roy C, Makowska A, Lum D, Sugita M, Podrebarac T, Koezuka Y, Porcelli S A, Cardell S, Brenner MB, Behar SM (2000) Murine CD1d-restricted T cell recognition of cellular lipids. Immunity 12:211-221

28. Hayakawa Y, Godfrey DI, Smyth MJ (2004) $\alpha$-galactosylceramide: potential immunomodulatory activity and future application. Curr Med Chem 11:241-252

29. Jenkinson HJ, Wainwright SD, Simpson KL, Perry AC, Fotiadou P, Holmes CH (1999) Expression of CD1D mRNA transcripts in human choriocarcinoma cell lines and placentally derived trophoblast cells. Immunology 96:649-655

30. Karadimitris A, Gadola S, Altamirano M, Brown D, Woolfson A, Klenerman P, Chen JL, Koezuka Y, Roberts IA, Price DA, Dusheiko G, Milstein C, Fersht A, Luzzatto L, Cerundolo V (2001) Human CD1d-glycolipid tetramers generated by in vitro oxidative refolding chromatography. Proc Natl Acad Sci USA 98:3294-3298 
31. Kawano T, Cui J, Koezuka Y, Toura I, Kaneko Y, Motoki K, Ueno H, Nakagawa R, Sato H, Kondo E, Koseki H, Taniguchi M (1997) CD1d-restricted and TCR-mediated activation of Va14 NKT cells by glycosylceramides. Science 278:1626-1629

32. Kenna T, Golden-Mason L, Norris S, Hegarty JE, O'Farrelly C, Doherty DG (2004) Distinct subpopulations of $\gamma \delta$ T cells are present in normal and tumour-bearing human liver. Clin Immunol 113:56-63

33. Kenna T, Golden-Mason L, Porcelli SA, Koezuka Y, Hegarty JE, O'Farrelly C, Doherty DG (2003) NKT cells from normal and tumour-bearing human livers are phenotypically and functionally distinct from murine NKT cells. J Immunol 171:1775-1779

34. Kinjo Y, Wu D, Kim G, Xing GW, Poles MA, Ho DD, Tsuji M, Kawahara K, Wong CH, Kronenberg M (2005) Recognition of bacterial glycosphingolipids by natural killer T cells. Nature 434:520-525

35. Kitamura H, Iwakabe K, Yahata T, Nishimura S, Ohta A, Ohmi Y, Sato M, Takeda K, Okumura K, Van Kaer L, Kawano T, Taniguchi M, Nishimura T (1999) The natural killer T (NKT) cell ligand $\alpha$-galactosylceramide demonstrates its immunopotentiating effect by inducing interleukin (IL)-12 production by dendritic cells and IL-12 receptor expression on NKT cells. J Exp Med 189:1121-1128

36. de Lalla C, Galli G, Aldrighetti L, Romeo R, Mariani M, Monno A, Nuti S, Colombo M, Callea F, Porcelli SA, PaninaBordignon P, Abrignani S, Casorati G, Dellabona P (2004) Production of profibrotic cytokines by invariant NKT cells characterizes cirrhosis progression in chronic viral hepatitis. J Immunol 173:1417-1425

37. Leslie DS, Vincent MS, Spada FM, Das H, Sugita M, Morita CT, Brenner MB (2002) CD1-mediated $\gamma \delta$ T cell maturation of dendritic cells. J Exp Med 196:1575-1584

38. Lucas M, Gadola S, Meier U, Young NT, Harcourt G, Karadimitris A, Coumi N, Brown D, Dusheiko G, Cerundolo V, Klenerman P (2003). Frequency and phenotype of circulating $\mathrm{V} \alpha 24 \mathrm{~V} \beta 11$ double-positive natural killer T cells during hepatitis $\mathrm{C}$ virus infection. J Virol 77:2251-2257

39. Mandal M, Chen XR, Alegre ML, Chiu NM, Chen YH, Castano AR, Wang CR (1998) Tissue distribution, regulation and intracellular localization of murine CD1 molecules. Mol Immunol 35:525-536

40. Moody DB, Ulrichs T, Muhlecker W, Young DC, Gurcha SS, Grant E, Rosat JP, Brenner MB, Costello CE, Besra GS, Porcelli SA (2000) CD1c-mediated T-cell recognition of isoprenoid glycolipids in Mycobacterium tuberculosis infection. Nature 404:884-888

41. Nakagawa R, Nagafune I, Tazunoki Y, Ehara H, Tomura H, Iijima R, Motoki K, Kamishohara M, Seki S (2001) Mechanisms of the antimetastatic effect in the liver and of the hepatocyte injury induced by $\alpha$-galactosylceramide in mice. J Immunol 166:6578-6584

42. Nieda M, Okai M, Tazbirkova A, Lin H, Yamaura A, Ide K, Abraham R, Juji T, Macfarlane DJ, Nicol AJ (2004) Therapeutic activation of $\mathrm{V} \alpha 24^{+} \mathrm{V} \beta 11^{+} \mathrm{NKT}$ cells in human subjects results in highly coordinated secondary activation of acquired and innate immunity. Blood 103:383-389

43. Norris S, Doherty DG, Collins C, McEntee G, Traynor O, Hegarty JE, O'Farrelly C (1999) Natural T cells in the human liver: cytotoxic lymphocytes with dual $\mathrm{T}$ cell and natural killer cell phenotype and function are phenotypically heterogenous and include $\mathrm{V} \alpha 24-\mathrm{J} \alpha \mathrm{Q}$ and $\gamma \delta \mathrm{T}$ cell receptor bearing cells. Hum Immunol 60:20-31

44. Park SH, Weiss A, Benlagha K, Kyin T, Teyton L, Bendelac A (2001) The mouse CD1d-restricted repertoire is dominated by a few autoreactive $\mathrm{T}$ cell receptor families. J Exp Med 193:893-904

45. Porcelli S, Brenner MB, Greenstein JL, Balk SP, Terhorst C, Bleicher PA (1989). Recognition of cluster of differentiation 1 antigens by human $\mathrm{CD}^{-} \mathrm{CD}^{-}$cytolytic $\mathrm{T}$ lymphocytes. Nature 341:447-450

46. Porcelli SA, Modlin RL (1999) The CD1 system: antigenpresenting molecules for $\mathrm{T}$ cell recognition of lipids and glycolipids. Annu Rev Immunol 17:297-329

47. Rosat JP, Grant EP, Beckman EM, Dascher CC, Sieling PA, Frederique D, Modlin RL, Porcelli SA, Furlong ST, Brenner MB (1999) CD1-restricted microbial lipid antigen-specific recognition found in the $\mathrm{CD}^{+} \alpha \beta \mathrm{T}$ cell pool. J Immunol 162:366-371

48. Shamshiev A, Donda A, Carena I, Mori L, Kappos L, De Libero G (1999) Self glycolipids as T-cell autoantigens. Eur J Immunol 29:1667-1675

49. Shamshiev A, Gober HJ, Donda A, Mazorra Z, Mori L, De Libero G (2002) Presentation of the same glycolipid by different CD1 molecules. J Exp Med 195:1013-1021

50. Smyth MJ, Taniguchi M, Street SE (2000) The anti-tumour activity of IL-12: mechanisms of innate immunity that are model and dose dependent. J Immunol 165:2665-2670

51. Sonoda KH, Faunce DE, Taniguchi M, Exley M, Balk S, Stein-Streilein J (2001) NK T cell-derived IL-10 is essential for the differentiation of antigen-specific $\mathrm{T}$ regulatory cells in systemic tolerance. J Immunol 166:42-50

52. Spada FM, Borriello F, Sugita M, Watts GF, Koezuka Y, Porcelli SA (2000) Low expression level but potent antigen presenting function of CD1d on monocyte lineage cells. Eur J Immunol 30:3468-3477

53. Spada FM, Grant EP, Peters PJ, Sugita M, Melian A, Leslie DS, Lee HK, van Donselaar E, Hanson DA, Krensky AM, Majdic O, Porcelli SA, Morita CT, Brenner MB (2000) Selfrecognition of $\mathrm{CD} 1$ by $\gamma \delta \mathrm{T}$ cells: implications for innate immunity. J Exp Med 191:937-948

54. Stenger S, Niazi KR, Modlin RL (1998) Down-regulation of $\mathrm{CD} 1$ on antigen-presenting cells by infection with Mycobacterium tuberculosis. J Immunol 161:3582-3588

55. Tahir SM, Cheng O, Shaulov A, Koezuka Y, Bubley GJ, Wilson SB, Balk SP, Exley MA (2001) Loss of IFN- $\gamma$ production by invariant NK $\mathrm{T}$ cells in advanced cancer. J Immunol 167:4046-4050

56. Tomura M, Yu WG, Ahn HJ, Yamashita M, Yang YF, Ono S, Hamaoka T, Kawano T, Taniguchi M, Koezuka Y, Fujiwara $\mathrm{H}$ (1999) A novel function of $\mathrm{V} \alpha 14^{+} \mathrm{CD} 4^{+} \mathrm{NKT}$ cells: stimulation of IL-12 production by antigen-presenting cells in the innate immune system. J Immunol 163:93-101

57. Tsuneyama K, Yasoshima M, Harada K, Hiramatsu K, Gershwin ME, Nakanuma Y (1998) Increased CD1d expression on small bile duct epithelium and epithelioid granuloma in livers in primary biliary cirrhosis. Hepatology 28:620-623

58. Vincent MS, Leslie DS, Gumperz JE, Xiong X, Grant EP, Brenner MB (2002) CD1-dependent dendritic cell instruction. Nat Immunol 3:1163-1168

59. Yanagisawa K, Seino K, Ishikawa Y, Nozue M, Todoroki T, Fukao K (2002) Impaired proliferative response of V $\alpha 24$ NKT cells from cancer patients against $\alpha$-galactosylceramide. J Immunol 168:6494-6499

60. Zhou D, Mattner J, Cantu III C, Schrantz N, Yin N, Gao Y, Sagiv Y, Hudspeth K, Wu YP, Yamashita T, Teneberg S, Wang D, Proia RL, Levery SB, Savage PB, Teyton L, Bendelac A (2004) Lysosomal glycosphingolipid recognition by NKT cells. Science 306:1786-1789 